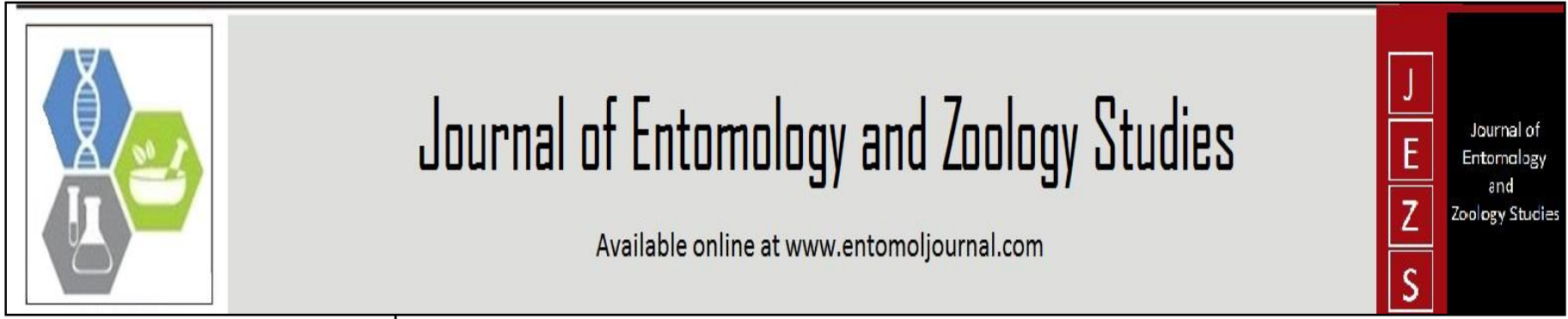

E-ISSN: 2320-7078

P-ISSN: 2349-6800

www.entomoljournal.com JEZS 2020; 8(5): 2346-2351 (C) $2020 \mathrm{JEZS}$

Received: 19-07-2020

Accepted: 23-08-2020

RK Anish

Department of Veterinary,

Parasitology, College of Veterinary

Science, Sri Venkateswara Veterinary

University, Tirupati, Andhra

Pradesh, India

Ravipati Venu

Department of Veterinary,

Parasitology, College of Veterinary

Science, Sri Venkateswara Veterinary

University, Tirupati, Andhra

Pradesh, India

VC Rayulu

Department of Veterinary,

Parasitology, College of Veterinary

Science, Sri Venkateswara Veterinary

University, Tirupati, Andhra

Pradesh, India

Siju S Jacob

NIVEDI, Bengaluru, Karnataka,

India

CH Srilatha

Department of Veterinary Pathology,

India

\section{UNS Surya}

Department of Veterinary,

Parasitology, College of

Veterinary Science, Sri

Venkateswara Veterinary

University, Tirupati, Andhra

Pradesh, India

\section{BS Pradeep}

Department of Veterinary,

Parasitology, College of

Veterinary Science, Sri

Venkateswara Veterinary

University, Tirupati, Andhra

Pradesh, India

\section{Tnvkv Prasad}

Regional Agricultural Research Station, ANGRAU, Bapatla,

Andhra Pradesh, India

\section{Corresponding Author:}

Ravipati Venu

Department of Veterinary,

Parasitology, College of Veterinary

Science, Sri Venkateswara Veterinary

University, Tirupati, Andhra

Pradesh, India

\section{Prevalence and diversity of ixodid tick fauna in domestic animals of Andhra Pradesh state, India}

\author{
RK Anish, Ravipati Venu, VC Rayulu, Siju S Jacob, CH Srilatha, UNS \\ Surya, BS Pradeep And Tnvkv Prasad
}

DOI: $\underline{\text { https://doi.org/10.22271/j.ento.2020.v8.i5af.7825 }}$

\section{Abstract}

Tick infestation in domestic animals is one of the serious health problems throughout the globe, especially in tropical countries. The present study was conducted to determine the prevalence and diversity of ixodid tick fauna of domestic animals from all 13 districts of Andhra Pradesh state, India. The study was conducted from May 2019 to March 2020. A total of 870 cattle, 602 buffaloes, 736 sheep, 754 goats, and 492 dogs were examined and out of which 717 (82.41\%), 441 (73.26\%), 592 (80.43\%), $604(80.11 \%)$, and $382(77.64 \%)$ cattle, buffaloes, sheep, goats, and dogs, respectively were infested with ixodid ticks with an overall prevalence rate of $79.21 \%$ (2736/3454). The most prevalent ixodid tick species is Rhipicephalus (Boophilus) microplus (54.28\%), followed by Rhipicephalus (Boophilus) annulatus (13.23\%), Hyalomma marginatum (10.25\%), Hyalomma anatolicum (9.23\%), Rhipicephalus sanguineus $(9.18 \%)$, Haemaphysalis bispinosa $(2.03 \%)$, Rhipicephalus haemaphysaloides $(1.70 \%)$ and Amblyomma integrum (0.10\%). The high prevalence of tick infestation in the current study alarms the field veterinarians to establish an effective preventive measure against ticks and tick-borne diseases in domestic animals of Andhra Pradesh state, India.

Keywords: Ixodid ticks, prevalence, diversity, domestic animals, Andhra Pradesh

\section{Introduction}

India is the agriculture based country and $70 \%$ of the rural households own livestock for livelihood and generating income and employment through milk, meat, and wool production [1]. The major constraints in animal rearing are the parasitic infections. Among these, ixodid tick infestation is one of the serious problems ${ }^{[2]}$. Ixodid ticks are economically the most important arthropod vectors of domestic and wild animals and more than $80 \%$ of the world cattle population is infested with ticks ${ }^{[3]}$. Tick borne diseases primarily affect the livelihood of poor farming communities. These problems are more pronounced in livestock and pet animals of tropical and sub-tropical countries particularly middle income group countries like India ${ }^{[4]}$. Tick infestation may cause direct losses through tick worry, blood loss, and damage to tanneries by decreasing the value of skin and hides.

Indirect losses by reduction in milk and meat yield, stunted growth or through transmission of bacterial, viral, rickettsial and haemoprotozoan diseases to domestic animals ${ }^{[5]}$. One female engorged tick is imposes a daily loss of $0.5-2.0 \mathrm{ml}$ of blood, $8.9 \mathrm{ml}$ of milk and one gram of body weight ${ }^{[6]}$. The estimated annual global costs associated with ticks and tick-transmitted pathogens in cattle amounts to between US\$ 13.9 billion and US\$ 18.7 billion ${ }^{[7]}$, while the cost of management of tick and tick borne diseases in livestock of India is as high as US\$ 498.7 million per annum ${ }^{[6,8]}$. Various studies reported, Rhipicephalus (Boophilus) microplus, Hyalomma anatolicum anatolicum, Hyalomma marginatum isacci and Rhipicephalus haemaphysaloides ticks from almost all states of India ${ }^{[9]}$. A systematic study on ixodid tick infestation in domestic animals in Andhra Pradesh is lacking except a report in cattle ${ }^{[10]}$. Hence, the current study was aimed to report the prevalence and diversity of ixodid ticks in cattle, buffaloes, sheep, goats and dogs of Andhra Pradesh state to provide a baseline data on ixodid tick fauna to evolve a suitable strategic anti-tick measures.

\section{Materials and Methods}

\subsection{Study area}

The state of Andhra Pradesh in India lies between $12^{\circ} 41^{\prime}$ and $19.07^{\circ} \mathrm{N}$ latitude and $77^{\circ}$ and $84^{\circ} 40^{\prime} \mathrm{E}$ longitude, and is bordered by Telangana, Chhattisgarh, and Orissa in the north, 
the Bay of Bengal in the East, Tamil Nadu to the south and Karnataka to the west. Andhra Pradesh has got a coastline of around $974 \mathrm{~km}$ and the climate is generally hot and humid. The present study was conducted in all the 13 districts of Andhra Pradesh viz., Chittoor, Kadapa, Anantapur, Kurnool, Nellore, Prakasam, Guntur, Krishna, West Godavari, East Godavari, Visakhapatnam, Srikakulam and Vizianagaram. Four places in each district were selected for collection of ticks to establish the distribution pattern of ixodid ticks in domestic animals (Fig. 1).

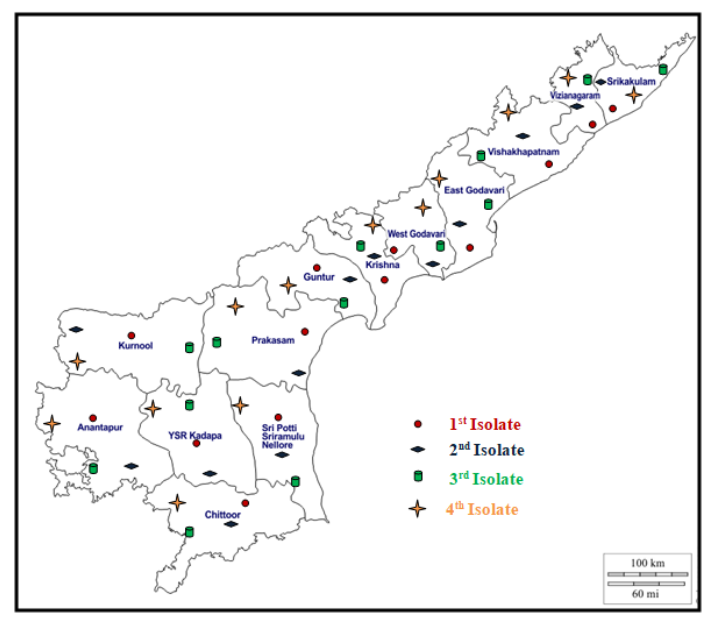

Fig 1: Particulars of tick collection in Andhra Pradesh state, India

\subsection{Ixodid tick collection}

A total of 3454 domestic animals comprising of cattle $(n=870)$, buffaloes $(n=602)$, sheep $(n=736)$, goats $(754)$ and dogs $(n=492)$ from 13 districts of Andhra Pradesh state, India were randomly selected and they were subjected to thorough investigation by close observation, separating the hairs for the detection of hard ticks. The sampled domestic ruminants were reared in intensive, semi-intensive and free ranging systems. Ticks were also collected from the stray dogs and pet dogs which were brought to veterinary dispensaries. The period of collection of ticks was from February 2019 to March 2020.

Ticks were collected carefully from the different parts of the body of the individual animal species by hand picking. In some instances, a small brush dipped in ethanol was used for the collection of ticks. The point of attachment of tick with the animal body was smeared with ethanol. Adequate precautions were taken to preserve the mouth parts and appendages of the ticks during collection. The collected ixodid ticks were preserved in $70 \%$ ethanol in a clean, wellstopper sample vial which was labelled properly ${ }^{[11,12]}$.

\subsection{Processing and identification of ticks}

The morphological study for the identification of the ticks was conducted at the Department of Veterinary Parasitology, College of Veterinary Science, Sri Venkateswara Veterinary University, Tirupati, Andhra Pradesh. Presumptive identification of samples was made under dissecting stereomicroscope $(4 \mathrm{x}, 10 \mathrm{x})$. Ticks were processed as per the standard protocols briefly, boiled in $5-10 \%$ of $\mathrm{KOH}$, dehydrated in ascending grades of ethanol $(50 \%, 70 \%, 90 \%$ and absolute), cleared (carbolic acid) and mounted (D.P.X.) and the final identification was made under stereo zoom microscope $(10 \mathrm{x}, 40 \mathrm{x})$ by preparing permanent mounts following the procedures described by ${ }^{[13]}$. The ixodids were identified based on the standard morphological features ${ }^{[14-17]}$.

\subsection{Statistical analysis}

The prevalence data was subjected to Karl Pearson's Chi square test of independent variables and Duncon One way ANOVA (ANOVA by single factor) with $5 \%$ level of significance $p<0.05$ to assess if there is any significant difference in the animals among various species using Windows version 6.1 and Microsoft version 13.

\section{Results}

In the current study, domestic animals were heavily infested with tick infestation and ranges from $73.26 \%$ to $82.41 \%$. Out of 870 cattle, 602 buffaloes, 736 sheep, 754 goats and 492 dogs examined, $717(82.41 \%)$ cattle, $441(73.26 \%)$ buffaloes, $592(80.43 \%)$ sheep, $604(80.11 \%)$ goats and $382(77.64 \%)$ dogs were infested with ticks with an overall prevalence of $79.21 \%$ (2736/3454). Statistically, no significant difference was observed regarding the prevalence rate between the animal hosts $(p<0.05)$ (Table 1$)$.

Table 1: Prevalence of ixodid ticks of domestic animals of Andhra Pradesh state, India

\begin{tabular}{|c|c|c|c|}
\hline $\begin{array}{c}\text { Domestic } \\
\text { animal }\end{array}$ & $\begin{array}{c}\text { Number } \\
\text { examined }\end{array}$ & $\begin{array}{c}\text { Number infested } \\
\text { with ticks }\end{array}$ & $\begin{array}{c}\text { Percent } \\
(\boldsymbol{\%})\end{array}$ \\
\hline Cattle & 870 & 717 & 82.41 \\
\hline Buffalo & 602 & 441 & 73.26 \\
\hline Sheep & 736 & 592 & 80.43 \\
\hline Goat & 754 & 604 & 80.11 \\
\hline Dog & 492 & 382 & 77.64 \\
\hline Total & 3454 & 2736 & 79.21 \\
\hline
\end{tabular}

A total of eight different types of ticks were identified based on the morphological characters viz., Rhipicephalus (Boophilus) microplus, Rhipicephalus (Boophilus) annulatus, Hyalomma marginatum, Hyalomma anatolicum, Rhipicephalus sanguineus, Rhipicephalus haemaphysaloides, Haemaphysalis bispinosa and Amblyomma integrum (Fig. 2). The host wise distribution of different species of ticks in each district is depicted in Table 2.

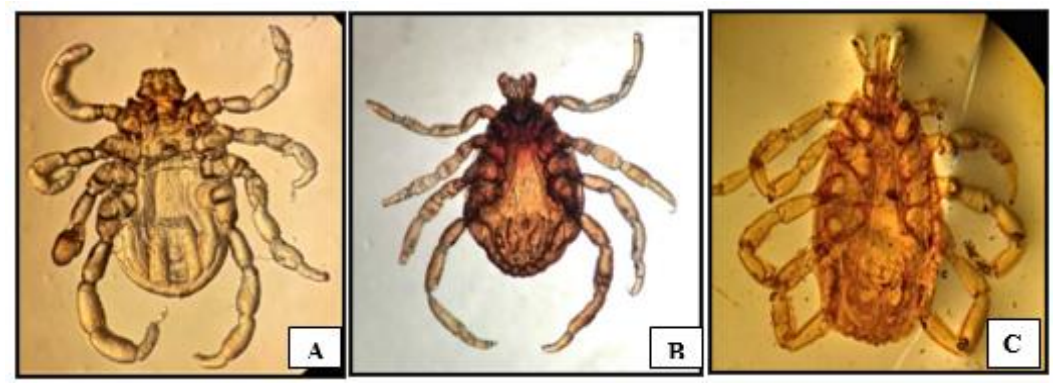




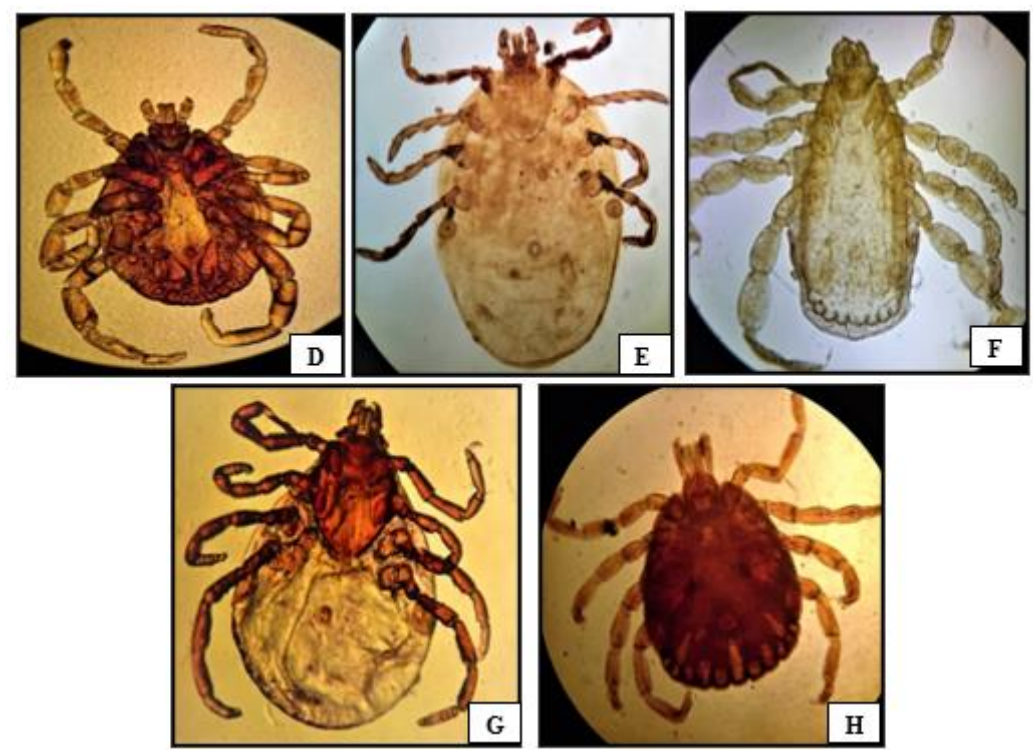

Fig 2: Different ixodid tick species identified in domestic animals of Andhra Pradesh state, India A) Rhipicephalus (Boophilus) microplus; B) Rhipicephalus (Boophilus) annulatus C) Hyalomma marginatum D) Hyalomma anatolicum E) Haemaphysalis bispinosa $\mathbf{F})$ Rhipicephalus sanguineus $\mathbf{G )}$ Rhipicephalus haemaphysaloides $\mathbf{H})$ Amblyomma integrum

Table 2: Ixodid tick diversity in domestic animals of Andhra Pradesh state, India

\begin{tabular}{|c|c|c|c|c|c|c|}
\hline \multirow{2}{*}{ S. No. } & \multirow{2}{*}{ District } & \multicolumn{5}{|c|}{ Ixodid tick species } \\
\hline & & Cattle & Buffalo & Sheep & Goat & Dog \\
\hline 1. & Chittoor & $\mathrm{R}(\mathrm{B}) \mathrm{m}, \mathrm{R}(\mathrm{B}) \mathrm{a}, \mathrm{Ha}, \mathrm{Hm}$ & $\mathrm{R}(\mathrm{B}) \mathrm{m}, \mathrm{R}(\mathrm{B}) \mathrm{a}, \mathrm{Hm}$ & $\mathrm{R}(\mathrm{B}) \mathrm{m}, \mathrm{R}(\mathrm{B}) \mathrm{a}, \mathrm{Ha}, \mathrm{Hm}, \mathrm{Hb}$ & $\mathrm{R}(\mathrm{B}) \mathrm{m}, \mathrm{R}(\mathrm{B}) \mathrm{a}, \mathrm{Hb}, \mathrm{Hm}$ & Rs \\
\hline 2. & Kadapa & $\mathrm{R}(\mathrm{B}) \mathrm{m}, \mathrm{R}(\mathrm{B}) \mathrm{a}, \mathrm{Ha}, \mathrm{Hm}$ & $\mathrm{R}(\mathrm{B}) \mathrm{m}, \mathrm{R}(\mathrm{B}) \mathrm{a}, \mathrm{Ha}$ & $\mathrm{R}(\mathrm{B}) \mathrm{m}, \mathrm{R}(\mathrm{B}) \mathrm{a}, \mathrm{Hb}, \mathrm{Hm}$ & $\mathrm{R}(\mathrm{B}) \mathrm{m}, \mathrm{R}(\mathrm{B}) \mathrm{a}, \mathrm{Ha}, \mathrm{Hb}, \mathrm{Hm}$ & Rs \\
\hline 3. & Anantapur & $\mathrm{R}(\mathrm{B}) \mathrm{m}, \mathrm{R}(\mathrm{B}) \mathrm{a}, \mathrm{Hm}$ & $\mathrm{R}(\mathrm{B}) \mathrm{m}, \mathrm{R}(\mathrm{B}) \mathrm{a}, \mathrm{Ha}, \mathrm{Hm}$ & R(B)m, R(B)a, Ha, Hb & $\mathrm{R}(\mathrm{B}) \mathrm{m}, \mathrm{R}(\mathrm{B}) \mathrm{a}, \mathrm{Hb}, \mathrm{Hm}$ & Rs \\
\hline 4. & Kurnool & $\mathrm{R}(\mathrm{B}) \mathrm{m}, \mathrm{R}(\mathrm{B}) \mathrm{a}, \mathrm{Ha}, \mathrm{Hm}$ & $\mathrm{R}(\mathrm{B}) \mathrm{m}, \mathrm{R}(\mathrm{B}) \mathrm{a}, \mathrm{Hm}$ & $\mathrm{R}(\mathrm{B}) \mathrm{m}, \mathrm{R}(\mathrm{B}) \mathrm{a}, \mathrm{Hb}, \mathrm{Hm}$ & $\mathrm{R}(\mathrm{B}) \mathrm{m}, \mathrm{R}(\mathrm{B}) \mathrm{a}, \mathrm{Ha}, \mathrm{Hb}$ & $\mathrm{Rs}, \mathrm{Rh}$ \\
\hline 5. & Nellore & $\mathrm{R}(\mathrm{B}) \mathrm{m}, \mathrm{R}(\mathrm{B}) \mathrm{a}, \mathrm{Ha}, \mathrm{Hm}$ & $\mathrm{R}(\mathrm{B}) \mathrm{m}, \mathrm{R}(\mathrm{B}) \mathrm{a}, \mathrm{Ha}, \mathrm{Hm}$ & $\mathrm{R}(\mathrm{B}) \mathrm{m}, \mathrm{R}(\mathrm{B}) \mathrm{a}, \mathrm{Ha}, \mathrm{Hm}$ & $\mathrm{R}(\mathrm{B}) \mathrm{m}, \mathrm{R}(\mathrm{B}) \mathrm{a}, \mathrm{Ha}, \mathrm{Hm}$ & Rs \\
\hline 6. & Prakasam & $\mathrm{R}(\mathrm{B}) \mathrm{m}, \mathrm{R}(\mathrm{B}) \mathrm{a}, \mathrm{Ha}, \mathrm{Hm}$ & $\mathrm{R}(\mathrm{B}) \mathrm{m}, \mathrm{R}(\mathrm{B}) \mathrm{a}, \mathrm{Hm}$ & R(B)m, R(B)a, Ha, Hb & $\mathrm{R}(\mathrm{B}) \mathrm{m}, \mathrm{R}(\mathrm{B}) \mathrm{a}, \mathrm{Hb}, \mathrm{Hm}$ & Rs \\
\hline 7. & Guntur & $\mathrm{R}(\mathrm{B}) \mathrm{m}, \mathrm{R}(\mathrm{B}) \mathrm{a}, \mathrm{Ha}$ & $\mathrm{R}(\mathrm{B}) \mathrm{m}, \mathrm{R}(\mathrm{B}) \mathrm{a}, \mathrm{Hm}$ & $\mathrm{R}(\mathrm{B}) \mathrm{m}, \mathrm{R}(\mathrm{B}) \mathrm{a}, \mathrm{Hb}, \mathrm{Hm}$ & $\mathrm{R}(\mathrm{B}) \mathrm{m}, \mathrm{R}(\mathrm{B}) \mathrm{a}, \mathrm{Ha}, \mathrm{Hb}$ & $\mathrm{Rs}, \mathrm{Rh}$ \\
\hline 8. & Krishna & R(B)m, R(B)a, Ha & $\mathrm{R}(\mathrm{B}) \mathrm{m}, \mathrm{R}(\mathrm{B}) \mathrm{a}, \mathrm{Hm}$ & $\mathrm{R}(\mathrm{B}) \mathrm{m}, \mathrm{R}(\mathrm{B}) \mathrm{a}, \mathrm{Hb}, \mathrm{Hm}$ & $\mathrm{R}(\mathrm{B}) \mathrm{m}, \mathrm{R}(\mathrm{B}) \mathrm{a}, \mathrm{Ha}, \mathrm{Hm}$ & Rs \\
\hline 9. & West Godavari & $\mathrm{R}(\mathrm{B}) \mathrm{m}, \mathrm{R}(\mathrm{B}) \mathrm{a}, \mathrm{Ha}, \mathrm{Hm}$ & $\mathrm{R}(\mathrm{B}) \mathrm{m}, \mathrm{R}(\mathrm{B}) \mathrm{a}, \mathrm{Ha}, \mathrm{Hm}$ & $\mathrm{R}(\mathrm{B}) \mathrm{m}, \mathrm{R}(\mathrm{B}) \mathrm{a}, \mathrm{Hb}, \mathrm{Hm}$ & $\mathrm{R}(\mathrm{B}) \mathrm{m}, \mathrm{R}(\mathrm{B}) \mathrm{a}, \mathrm{Hb}, \mathrm{Hm}$ & Rs \\
\hline 10. & East Godavari & $\mathrm{R}(\mathrm{B}) \mathrm{m}, \mathrm{R}(\mathrm{B}) \mathrm{a}$ & $\mathrm{R}(\mathrm{B}) \mathrm{m}, \mathrm{R}(\mathrm{B}) \mathrm{a}, \mathrm{Hm}$ & $\mathrm{R}(\mathrm{B}) \mathrm{m}, \mathrm{R}(\mathrm{B}) \mathrm{a}, \mathrm{Hb}$ & $\mathrm{R}(\mathrm{B}) \mathrm{m}, \mathrm{R}(\mathrm{B}) \mathrm{a}, \mathrm{Hm}$ & $\mathrm{Rs}, \mathrm{Rh}$ \\
\hline 11. & Visakhapatnam & $\mathrm{R}(\mathrm{B}) \mathrm{m}, \mathrm{R}(\mathrm{B}) \mathrm{a}, \mathrm{Hm}$ & $\mathrm{R}(\mathrm{B}) \mathrm{m}, \mathrm{R}(\mathrm{B}) \mathrm{a}, \mathrm{Ha}$ & $\mathrm{R}(\mathrm{B}) \mathrm{m}, \mathrm{R}(\mathrm{B}) \mathrm{a}, \mathrm{Hm}$ & $\mathrm{R}(\mathrm{B}) \mathrm{m}, \mathrm{R}(\mathrm{B}) \mathrm{a}$ & $\mathrm{Rs}, \mathrm{Rh}$ \\
\hline 12. & Srikakulam & R(B)m, R(B)a, Ha, Hm, & $\mathrm{R}(\mathrm{B}) \mathrm{m}, \mathrm{R}(\mathrm{B}) \mathrm{a}, \mathrm{Ha}, \mathrm{Hm}$ & $\mathrm{R}(\mathrm{B}) \mathrm{m}, \mathrm{R}(\mathrm{B}) \mathrm{a}, \mathrm{Ha}, \mathrm{Hb}, \mathrm{Hm}$ & $\mathrm{R}(\mathrm{B}) \mathrm{m}, \mathrm{R}(\mathrm{B}) \mathrm{a}, \mathrm{Hb}, \mathrm{Hm}$ & $\mathrm{Rs}, \mathrm{Rh}$ \\
\hline 13. & Vizianagaram & $\mathrm{R}(\mathrm{B}) \mathrm{m}, \mathrm{R}(\mathrm{B}) \mathrm{a}, \mathrm{Ha}, \mathrm{Hm}, \mathrm{Ai}$ & $\mathrm{R}(\mathrm{B}) \mathrm{m}, \mathrm{R}(\mathrm{B}) \mathrm{a}, \mathrm{Ha}, \mathrm{Hm}$ & $\mathrm{R}(\mathrm{B}) \mathrm{m}, \mathrm{R}(\mathrm{B}) \mathrm{a}, \mathrm{Ha}, \mathrm{Hb}, \mathrm{Hm}$ & $\mathrm{R}(\mathrm{B}) \mathrm{m}, \mathrm{R}(\mathrm{B}) \mathrm{a}, \mathrm{Ha}, \mathrm{Hb}, \mathrm{Hm}$ & Rs \\
\hline
\end{tabular}

Note: R(B)m: Rhipicephalus (Boophilus) microplus; R(B)a: Rhipicephalus (Boophilus) annulatus; Ha: Hyalomma anatolicum; Hm: Hyalomma marginatum; Hb: Haemaphysalis bispinosa; Rs: Rhipicephalus sanguineus; Rh: Rhipicephalus haemaphysaloides; Ai: Amblyomma integrum.

In the current study, Rhipicephalus (Boophilus) microplus $(54.28 \%)$ was the most predominant tick species observed, followed by Rhipicephalus (Boophilus) annulatus (13.23\%), Hyalomma marginatum (10.25\%), Hyalomma anatolicum
(9.23\%), Rhipicephalus sanguineus (9.18\%), Haemaphysalis bispinosa (2.03\%), Rhipicephalus haemaphysaloides (1.70\%) and Amblyomma integrum (0.10\%) (Fig. 3).

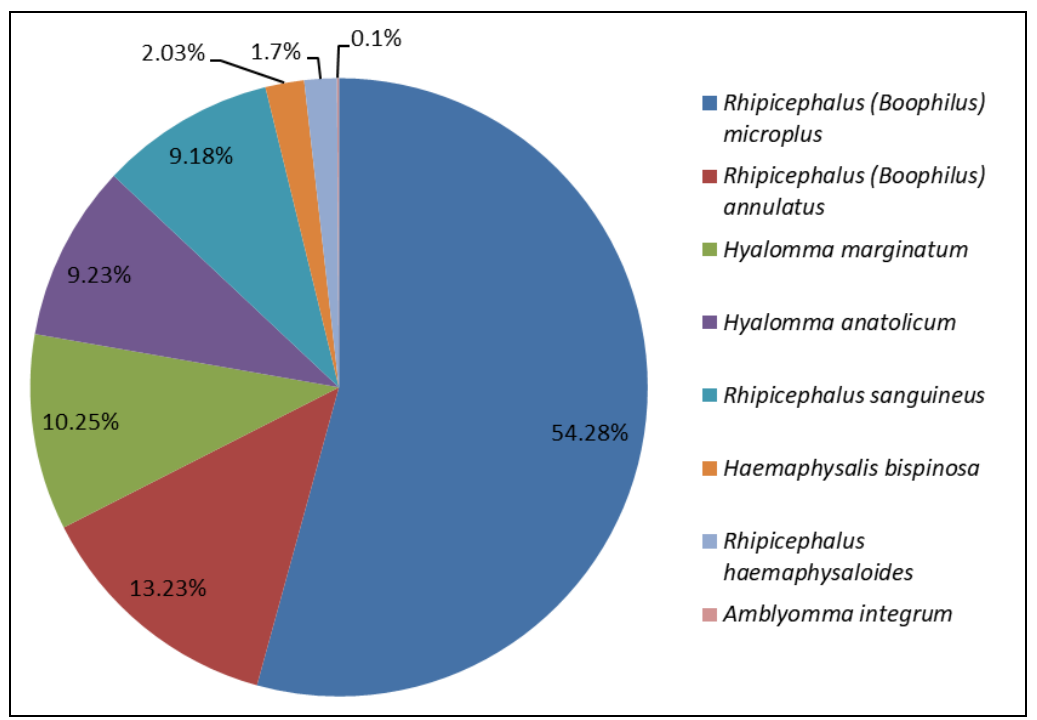

Fig 3: Distribution of ixodid ticks in domestic animals of Andhra Pradesh state, India $\sim 2348 \sim$ 
Ixodid tick species, Rhipicephalus (Boophilus) microplus and $R(B$.) annulatus were found in all domestic ruminants. Apart from these, Hyalomma anatolicum, H. marginatum and Haemaphysalis bispinosa were recorded either as a single or mixed infestation in cattle, buffaloes, sheep and goats, while Amblyomma integrum was noted only in cattle at Vizianagaram district. In small ruminants, Haemaphysalis bispinosa was observed. In dogs, Rhipicephalus sanguineus was the predominant tick species and found in dogs of 13 districts in the state, whereas $R$. haemaphysaloides was confined to the dogs of five districts viz., Kurnool, Kadapa, East Godavari, Visakhapatnam and Srikakulam.

\section{Discussion}

The current study on prevalence and distribution pattern on ixodid tick infestation was conducted in domestic animals involving cattle, buffaloes, sheep, goat and dogs in Andhra Pradesh state, India. In a study in Tamil Nadu reported the prevalence of tick infestation in domestic ruminants ${ }^{[18]}$. Similarly, in cattle and buffaloes tick infestation was recorded in the states of Punjab, Kerala and Gujarat ${ }^{[19-21]}$. In contrast, several workers published reports on ixodid tick infestation in cattle of various Indian states ${ }^{[22-29]}$. Recently, prevalence of ticks in sheep and goats of Tamil Nadu ${ }^{[30]}$ and Karnataka [31] states were recorded and exclusively from goats of Uttarakhand state also reported ${ }^{[32]}$.

In the current study, domestic animals were noted with heavily infested tick infestations at an overall prevalence of $79.21 \%$. The highest prevalence of was noted in cattle $(82.41 \%)$, followed by sheep $(80.43 \%)$, goats $(80.11 \%)$, dogs $(77.64 \%)$ and buffaloes $(73.26 \%)$. In cattle, the low prevalence of infestation $(41.93 \%$ to $64.07 \%$ ) was reported by earlier workers from different parts of country viz., Uttar Pradesh [23, 25]; West Bengal [24]; Odisha [26]; Mizoram [27]; Jammu region [28]; Uttaranchal [33] and Punjab ${ }^{[34]}$. However, higher prevalence rate was noted at $77.91 \%$ in cattle of monsoon season in Mizoram ${ }^{[27]}$ and $80.21 \%$ in $<1$ year old cattle ${ }^{[23]}$ in Uttar Pradesh. This clearly indicates the variations in the prevalence rates may be significantly influenced by risk factors such as age of the animal and season prevailed during the sampled areas. In buffaloes, a prevalence rate at $73.26 \%$ was noted in the present study. Very low prevalence rate was noted in Kerala ${ }^{[20]}$ and a moderately low and high prevalence rate of infestation was noted in Punjab ${ }^{[19]}$ and Gujarat ${ }^{[21]}$. In sheep and goats, the prevalence of tick infestation was observed in Tamil Nadu state ${ }^{[30]}$, whereas slightly higher rate was reported in Karnataka state ${ }^{[31]}$. In goats, the current prevalence rate of infection was somewhat similar to the previous findings from Uttarakhand ${ }^{[32]}$.

The attributed reasons for variations in the prevalence of tick infestations may be due to the management practices including the use of acaricides and animal holdings influence the tick infestations on the body of the host. The animals maintained under extensive system and in smaller holdings often harbour low grade tick infestations as they are regularly removed by hand picking or grooming of animals on return from grazing lands ${ }^{[35,36]}$. Reduction in the quality of animal health services, lack of standard animal husbandry practices and awareness on the harmful effects of ticks among the animal owners of rural areas have contributed much to the wide distribution of tick species in the areas under the study [22]. In dogs, higher prevalence of tick infestation was recorded and is in agreement with the previous findings ${ }^{[37,38]}$. In contrast, low prevalence was noted by others from various parts of India ${ }^{[39-41]}$.

In the present study, it was observed that the tick infestations were widely prevalent in domestic animals throughout the study area. This indicates the fact that tick infestation is a major constraint for the proper development and well-being of the livestock wealth of the state. The hot and humid climate of the state facilitates a favourable environment for the development and propagation of ticks.

In the present study, eight ixodids species were identified and the most predominant tick species was Rhipicephalus (Boophilus) microplus followed by Rhipicephalus (Boophilus) annulatus, Hyalomma marginatum, Hyalomma anatolicum, Rhipicephalus sanguineus, Haemaphysalis bispinosa, Rhipicephalus haemaphysaloides and Amblyomma integrum. Similar findings were reported from cattle in Andhra Pradesh [10]. Various studies reported tick infestations in domestic animals from different parts of India viz. Punjab [19, 34], Kerala [20, 43], Gujarat [21], Uttar Pradesh [23, 25], West Bengal [24], Odisha [26], Mizoram [27], Jammu [28], Tamil Nadu [30, 44], Uttarakhand ${ }^{[32,33]}$ and Maharashtra ${ }^{[42]}$.

Individual and mixed tick infestation in cattle in the present study was in accordance with the earlier findings ${ }^{[23,29]}$ from Uttar Pradesh and Chhattisgarh. Mixed tick infestation of $R$. (B) microplus, Hyalomma spp. and Haemaphysalis spp. in cattle in West Bengal was reported ${ }^{[24]}$. In dogs, mixed tick infestation of $R$. (B) microplus and Hyalomma anatolicum in cattle and Rhipicephalus sanguineus in costal districts of Odisha state was noted ${ }^{[26]}$. A report on mixed infestation of R. (B) microplus, Hyalomma marginatum, Haemaphysalis bispinosa and Rhipicephalus haemaphysaloides in cattle and sheep and Rhipicephalus sanguineus in dogs of rural and urban Bengaluru, Karnataka was also noted [31]. Previously, Hyalomma spp. Haemaphysalis bispinosa and Rhipicephalus haemaphysaloides in cattle, sheep and goat population and Rhipicephalus sanguineus in dogs of coastal areas of Tamil Nadu state was recorded ${ }^{[18]}$.

\section{Conclusion}

Based on the findings of the present study, it is evident that domestic animal population in Andhra Pradesh state are considerably burdened with tick infestation leading to a risk of contracting tick borne diseases. The observations from the present study may contribute to the increased understanding of epidemiology of ticks in the area. Therefore adoption of proper preventive measures, awareness on animal health services as well as proper application of acaricides might pave the way for the effective tick control under field conditions. Future studies are warranted by applying both the conventional and molecular techniques to establish the true epidemiologic status of the ixodid ticks of domestic animals under the study area.

\section{Acknowledgments}

The authors are thankful to Sri Venkateswara Veterinary University, Tirupati for providing facilities to conduct the study. The authors express gratitude to the field veterinarians for their help in collection of samples.

\section{Disclosure statement}

No potential conflict of interest was reported by the authors.

\section{References}

1. Ali J. Livestock sector development and implications for rural poverty alleviation in India. Livestock Research 
Rural Development. 2007;19(2):1-14.

2. Colebrook E, Wall R. Ectoparasites of livestock in Europe and the Mediterranean region. Veterinary Parasitology. 2004;120:251-274.

3. FAO. Ticks and tick-borne disease control. A practical field manual. Food and Agriculture Organization, Rome. 1984;1:246-299.

4. Perry BD, Randolph TF, Medermott JJ, Sones KR, Thornton PK. Investing in animal health research to alleviate poverty. International Livestock Research Institute, Nairobi, Kenya. Journal of Environmental Sciences. 2002;8:13-15.

5. Garcia Z. Integrated control of Boophilus microplus in cattle. In: Proc. 11th International Congress of International Society for Animal Hygiene, Mexico, 2003.

6. Minjauw B, McLeod A. Tick-borne diseases and poverty. The impact of ticks and tick-borne diseases on the livelihood of small scale and marginal livestock owners in India and Eastern and Southern Africa. Res Report, Animal DFID Health Programme, Centre for Tropical Veterinary Medicine, University of Edinburgh. 2003,5960.

7. Castro JJ, James AD, Minjauw B, Giulio GU, Permin A, Pegram RG, et al. Long-term studies on the economic impact of ticks on Sanga cattle in Zambia. Experimental and Applied Acarology. 1997;21(1):3-19.

8. Ghosh S, Bansal GC, Gupta SC, Ray D, Khan MQ, Irshad $\mathrm{H}$ et al. Status of tick distribution in Bangladesh, India and Pakistan. Parasitology Research. 2007;101(2):207-216.

9. Ghosh S, Azhahianambi P, Fuente J. Control of ticks of ruminants, with special emphasis on livestock farming systems in India: present and future possibilities for integrated control - a review. Experimental Applied Acarology. 2006;40(1):49-66.

10. Rajendran C, Hafeez MD. Prevalence of ixodid ticks on crossbred cattle in and around Tirupati. Journal of Veterinary Parasitology. 2003;17(2):147-149.

11. Rony SA, Mondal MMH, Begum N, Islam MA, Affroze S. Epidemiology of ectoparasitic infestations in cattle at Bhawal forest area, Gazipur. Bangladesh Journal of Veterinary Medicine. 2010;8(1):27-33.

12. Kaur D, Jaiswal K, Mishra S. Studies on prevalence of ixodid ticks infesting cattle and their control by plant extracts. IOSR Journal of Pharmacy and Biological Sciences. 2015;10(6):1-11.

13. Cable RM. An Illustrated Laboratory Manual of Parasitological. 4th ed., Minneapolis (MN): Burgess Publishing. 1967,111-132.

14. Sen SK, Fletcher, TB. Veterinary Entomology and Acarology for India. New Delhi: Indian Council of Agriculture Research Publishers. 1962,432-484.

15. Soulsby EJL. Helminths, Arthropods and Protozoa of domesticated animals. London: Bailliere Tindall. 1982, 630-654.

16. Wall R, Shearer D. Veterinary Entomology: Arthropod Ectoparasites of Veterinary Importance. 1st ed., London: Chapman and Hall. 1997,1-456.

17. Alan Walker. The arthropods of humans and domestic animals. 1st ed., London: Chapman and Hall Publishing. 2004,34-36.

18. Varadharajan A, Gnanasekar R, Kothandaraman S, Krishnan LM. Epidemiology of Ixodid ticks among domestic animals in coastal areas of Tamil Nadu, India.
Journal of Basic and Applied Research International. 2019;3:6-10.

19. Haque M, Singh NK, Rath SS, Ghosh S. Epidemiology and seasonal dynamics of ixodid ticks of dairy animals of Punjab state, India. Indian Journal of Animal Sciences. 2011;81(7):661.

20. Shyma KP, Stanley B, Ray DD, Ghosh S. Prevalence of cattle and buffalo ticks in northern Kerala. Journal of Veterinary Parasitology. 2013;27(1):55-56.

21. Patel DC, Solanki JB, Kumar N. Risk factors associated prevalence of hard ticks in large ruminants of coastal areas of South Gujarat, India. Indian Journal of Animal Research. 2019;53(11):1514-1517.

22. Kabir MHB, Mondal MMH, Eliyas M, Mannan MA, Hashem MA, Debnath NC et al. An epidemiological survey on investigation of tick infestation in cattle at Chittagong District, Bangladesh. African Journal of Microbiology Research. 2011;5(4):346-352.

23. Patel G, Shanker D, Jaiswal AK, Sudan V, Verma SK. Prevalence and seasonal variation in ixodid ticks on cattle of Mathura district, Uttar Pradesh. Journal of Parasitic Diseases. 2013;37(2):173-176.

24. Debbarma A, Pandita S, Jasa R, Baidyaa S, Mandala SC, Janab PS. Prevalence of hard tick infestations in cattle of West Bengal, India. Biological Rhythm Research. 2017;87:110-114.

25. Kaur D, Jaiswal K, Mishra S. Epidemiological study of ixodid ticks infesting cattle reared by small holder farmers. Journal of Entomology and Zoology Studies. 2017;4:284-291.

26. Dehuri M, Panda MR, Mohanty B, Hembram A, Mahapatra T, Sahu A. Ixodid ticks infesting cattle and associated risk factors in coastal districts of Odisha. Journal of Entomology and Zoology Studies. 2017;5(4):129-132.

27. Ghosh S, Patra G, Borthakur SK, Behera P, Tolenkhomba TC, Das M et al. Prevalence of hard tick infestations in cattle of Mizoram, India. Biological Rhythm Research. 2018;50(4):564-574.

28. Godara R, Katoch R, Yadav A. Prevalence of Ixodid Ticks in Cattle of Jammu Region. Veterinary Practitioner. 2018;19(1):27-28.

29. Jadhao SG, Sanyal PK, Borkar SD, Chigure GM, Jadhav ND, Shirsikar PM et al. Prevalence of ixodid ticks infesting in cattle of Chhattisgarh state, an east-central part of India. International Journal of Tropical Insect Science. 2020;3:17-20.

30. Soundararajan C, Nagarajan K, Muthukrishnan S, Prakash MA. Tick infestation on sheep, goat, horse and wild hare in Tamil Nadu. Journal of Parasitic Diseases. 2018;42(1):127-129.

31. Kage S, Mamatha GS, Lakkundi JN, Shivashankar BP, D'Souza PE. Prevalence of ixodid ticks on Babesia ovis infected sheep and goats in Karnataka state. Journal of Entomology Zoology Studies. 2019;7(4):511-515.

32. Gopalakrishnan A, Dimri U, Nandi A, Ajith Y, Joshi V, Jhambh R et al. Prevalence Study on Tick Infestations of Goat in Lower Shivalik Region of Uttarakhand. International Journal of Livestock Research. 2017;7(7):158-165.

33. Vatsya S, Yadav CL, Kumar RR, Garg R. x Prevalence of ixodid ticks on bovines in foothills of Uttarkhand state: A preliminary report. Indian Journal of Animal Sciences. 2017;68(6):224-229. 
34. Singh NK, Rath SS. Epidemiology of ixodid ticks in buffaloes (Bubalus bubalis) of Punjab, India. Buffalo Bulletin. 2016;35(3):347-353.

35. Latha BR, Aiyasami SS, Pattabiraman G, Sivaraman T, Rajavelu G. Seasonal activity of ticks on small ruminants in Tamil Nadu State, India. Tropical Animal Health and Production. 2004;36(2):123-133.

36. Ghai J, Singh M, Singh A. Population dynamics of ixodid ticks infesting cattle in Bathinda and Hoshiarpur districts in the Punjab State. Annals of Biology. 2008;24(1):95.

37. PedroPaulo VPD, Beall MJ, Omark K, Chandrashekar R, Daniluk DA, Cyr KE. High Prevalence of tick-borne pathogens in dogs from an Indian reservation in north eastern Arizona. Vector Borne and Zoonotic Diseases. 2010;10:117-123.

38. Murtazul-Hassan, Abubakar M, Muhammad Gh, Khan MN, Hussain M. Prevalence of Tick Infestation (Rhipicephalus sanguineus and Hyalomma anatolicum) in dogs in Punjab, Pakistan. Veterinaria Italiana. 2012; 48:95-98.

39. Sahu A, Mohanty B, Panda MR, Sardar KK, Dehuri M. Prevalence of tick infestation in dogs in and around Bhubaneswar. Vet World. 2013;6(12):982-985.

40. Krishnamurthy CM, Ananda KJ, Adeppa J. Prevalence of ectoparasites in dogs of Shimoga, Karnataka. Journal of Parasitic Diseases. 2017;41(1):167-170.

41. Laxmi Bai, Parveen Goel, Ricky Jhambh, Preeti. Rhipicephalus sanguineus tick prevalence in Ehrlichia canis infected dogs. Journal of Entomology and Zoology Studies. 2019;7(1):1516-1518.

42. Shahardar RA, Niphadkar SM, Narsapur VS, Gante ML. Ixodid ticks of cattle and buffaloes in coastal districts (Konkan region) of Maharashtra state. Indian Veterinary Journal. 1998;75(6):503-506.

43. Prakasan K, Ramani N. Tick parasites of domestic animals of Kerala, South India. Asian Journal of Animal and Veterinary Advances. 2007;2(2):74-80.

44. Vathsala M, Mohan P, Ramesh S. Survey of tick species distribution in sheep and goats in Tamil Nadu, India. Small Ruminant Research. 2008;74(1-3):238-242. 